\title{
J G Starke, QC
}

Joseph Gabriel Starke (known to all as Joe) died in Canberra on 24 February 2006, aged 94 . He had a truly remarkable life. One of his achievements was the foundation of the Year Book in which this tribute appears. There were greater achievements, spanning an extraordinarily wide range.

Joe Starke was born on 16 November 1911 in Western Australia into a family of merchants, who owned a chain of country stores. He was the second of four brothers, all of whom enjoyed notable careers. He was educated at Perth Modern School, the cradle of a number of distinguished Australians, and at the University of Western Australia, where he graduated BA and LLB (the latter with first class honours) in 1932.

Joe's first academic interest was mathematics, but his father persuaded him to study law. It is fortunate for readers of the Year Book that he was propelled into the law, but who is to say that he would not have become an equally distinguished mathematician or scientist? Indeed the breadth of his interests throughout his life, his attention to detail, and the taking up of unusual interests (for a lawyer), such as psychoanalysis, are evidence of an essentially scientific mind.

Joe won the Rhodes Scholarship for Western Australia in 1932. During his time at Oxford, where he read for the degree of Bachelor of Civil Laws, he was fortunate to be tutored by G C Cheshire at Exeter College, who influenced him greatly. (Later in life Joe was to edit the Australian edition of Cheshire and Fifoot on Contract Law.) At Oxford he also came under the influence of Felix Frankfurter, later to become a Justice of the Supreme Court of the United States, who at that time was a visiting professor in Oxford. It was Frankfurter who advised Joe to pursue a career in international law at a time when Joe was torn between accepting a position at the League of Nations in Geneva and returning home.

Despite a period of ill health shortly after arriving in Oxford, and the consequent need to concentrate his studies, Joe was declared by Professor Cheshire to be ready to take his final exams in June 1934. He was awarded first class honours in the BCL and the Vinerian Law Scholarship. A chance visit on holiday to Geneva awoke his interest in the League of Nations, and also in the prospect of taking courses at the Institute of International Studies. Permission was granted by the Rhodes Trustees and his College for him to spend the third year of his scholarship in Geneva. At the Institute he was taught by a number of distinguished scholars in international relations and international law, including Hans Kelsen, Paul Guggenheim, Hans Wehberg, Maurice Bourquin, and Carl Burckhardt. This confirmed Joe in his ambition to become an international lawyer. 
At the end of his course in 1935 a position fell vacant in the Opium Traffic Section of the League of Nations Secretariat. After consulting Frankfurter, Joe decided to apply. In 1937 he transferred to the Legal Secretariat of the League, and into an office in the magnificent newly built Palais des Nations. He remained there until January 1940, at which time most staff were retrenched because of the outbreak of the Second World War. During his time with the League, Joe was a witness to the momentous events of the time, including the Italian invasion of Abyssinia, the annexation of Austria by Germany, the Munich Agreement, and the expulsion of the Soviet Union from the League. In his official capacity, among many other important matters, Joe wrote the first draft of the legal opinion to the Secretary-General of the League that a protest against the Anschluss of Austria in March 1938 would be pointless. It also fell to Joe to write a reply to Leon Trotsky who, on learning that the League had adopted a Convention on Terrorism in 1937, wished to propose that the first person to be brought before the International Criminal Court should be Josef Stalin, 'the world's greatest terrorist'. Joe had to inform Trotsky that, regrettably, the Court had yet to be established. (It is pleasing that Joe lived long enough to see the establishment of the present International Criminal Court.)

Joe maintained a wide circle of acquaintances in Geneva, which enabled him to be informed of matters that fell outside his normal work. An important friendship was formed with Wilfred Jenks of the International Labour Organisation. (Wilfred Jenks's extensive personal library was later acquired by the University of New South Wales Law Library as the core of its international law collection). He and Jenks corresponded with Dr H V Evatt, at that time a Justice of the High Court of Australia, on the issue of the implementation of international labour conventions in federal states. ${ }^{1}$

Joe's experiences at the League of Nations from 1935 to 1940 are the subject of an extensive archive collected by the Oral History Section of the National Library of Australia in $1996 .{ }^{2}$ At that time it was thought that he was the last living Australian who had served in the League.

In January 1940 Joe returned to England. He had been called to the English Bar by the Inner Temple in 1939 (having had to make several short trips to London from Geneva in order to eat the required number of dinners). He appeared in a few cases, in one of which he was junior to A T Denning QC (later Lord Denning). However, when it became clear that the war was not going to end quickly, Joe accepted the arrangement under which the League paid for the return of its staff to their home countries.

Joe settled in Sydney after his return. He was invited to fill a temporary lectureship in international law following the death of Professor A H Charteris, Challis Professor of International Law. He performed this role from late 1940

1 See also J G Starke, 'Australia and the International Labour Organisation' in D P O'Connell (ed), International Law in Australia (1965) 115-140.

2 National Library of Australia, Canberra. ref no TRC 3524. The archive consists of 294 pages. 
until the arrival of Professor Julius Stone in 1942. He then enlisted for military service with RAAF Command HQ.

Entering into practice at the Sydney Bar did not cause Joe to lose interest in international law. He assisted Professor Stone in several projects. And he produced the first edition of his Introduction to International Law in 1947. He also wrote articles or notes on a number of international law topics, especially for the Australian Law Journal.

A measure of Joe's breadth of interests (since international law was hardly a specialisation one could pursue at the Sydney Bar), and of his acumen and industry, is that he took silk in 1961. Another measure is the books he published during his life on subjects other than international law. These included planning law, contract law, the law of choses in action, and psychoanalysis. ${ }^{3}$

In 1961 Joe decided to return to academic life on a permanent basis, having been offered a position as Senior Fellow in the Institute of Advanced Studies at the Australian National University in Canberra. The Law Department of the Institute consisted at that time of three scholars: Professor Geoffrey Sawer, Dr Samuel Stoljar, and Joe. There were no teaching responsibilities other than supervision of a few higher degree candidates. Joe was largely free to pursue his research and scholarly interests. He relinquished his appointment at ANU in 1976.

It is right to mention the inauguration of the Australian Year Book of International Law as a special achievement of Joe's during this period. He edited the first two issues. He also devised and wrote the Australian Practice in International Law section of the early Year Books. This section has since grown greatly in volume as the body of Australian practice has increased, and came in later years to engage the labours of officers of the Departments of the Attorney-General and Foreign Affairs and Trade. The section must now be regarded as a compilation of record and an essential research tool of all Australian international lawyers.

Some significant distinctions were conferred during and after Joe's time at ANU. He served as a Consultant to the Australian Law Reform Commission in 1975, and again in 1979-80. He was one of the four Australian members of the Panel of Arbitrators under the Hague Convention, which is the body that also makes nominations of candidates for election to the International Court of Justice. He lectured as a visiting professor at the Sorbonne in Paris in 1967. He was a visiting fellow later at the Max Planck Institute for Foreign, International and Public Law, Heidelberg, in 1972. He also taught at the International Institute of Humanitarian Law, San Remo, Italy from 1975.

The Law of Town and Country Planning in NSW (1965), The Law of Assignments of Choses in Action in Australia (1971), The Validity of Psychoanalysis (1973), The Contribution to Irenology in the Works of Leonard Nelson (1974), Cheshire \& Fifoot on Contract (with P F P Higgins) $\left(3^{\text {rd }}\right.$ ed, 1974 and the last $6^{\text {th }}$ edition, 1992, with N C Seddon and M P Ellinghaus), Case Book on the Law of Contract (with P F P Higgins and J P Swanton) (1975). 
In 1974 Joe had accepted the editorship of the Australian Law Journal, the principal journal read by practising lawyers in Australia. He had previously been a contributor to the journal on numerous topics, including the International Legal Notes section, which he initiated. He remained editor for a period of 18 years. This remarkable monument to Joe's industry was described in detail by Justice Michael Kirby in an extensive note published in the Journal in 1992.4

As well as a steady flow of articles, Joe wrote several monographs on international law: Studies in International Law (1965), The ANZUS Treaty Alliance (1965), and Introduction to the Science of Peace (1968, and $2^{\text {nd }}$ edition, 1986 with an introduction by Justice M D Kirby). Among his many contributions to periodicals, his article on the concept of opposability in international law in this Year Book attracted wide notice. ${ }^{5}$ It is typical of his pithy 'scientific' style.

International lawyers will remember Joe chiefly for his Introduction to International Law, which was written by him through ten editions from 1947 to 1989. He handed over this work to the present writer who produced an 11 th edition in 1994, now entitled Starke's International Law. A 12th edition is being prepared under the joint editorship of the present writer and Professor Ryszard Piotrowicz. It is a compendious work in traditional format, and it has achieved a wide readership in several languages. The late Professor D P O'Connell once advised his students that, when researching a topic in the general textbooks, 'never overlook Starke: you will often find things there that the other books have missed'.

The scientist was never absent from Joe's approach to law. On the much debated issue of the relationship between international law and domestic law, Joe favoured the monist position, that is, that all law is one, as against the dualist position that places international and domestic law on different planes, requiring an 'adoption' by the latter of the former. This was consistent with his own widespread interests in the law, and with the teachings of his professor of international law in Geneva, Hans Kelsen. In his textbook he wrote:

Once it be accepted as a hypothesis that international law is a system of rules of a truly legal character, it was impossible, according to Kelsen (1881-1973) and other monist writers to deny that the two systems constitute part of that unity corresponding to the unity of legal science. Thus any construction other than monism, and in particular dualism, is bound to amount to a denial of the true character of international law. There cannot in the view of the monist writers be any escape from the position that the two systems, because they are both systems of legal rules, are interrelated parts of the one legal structure. ${ }^{6}$

4 (1992) 66 Australian Law Journal 111-15. See also Justice Kirby's obituary in (2006) 80 Australian Law Journal 331-32.

5 'The concept of opposability in international law' Aust YBIL 1968-1969, 1-4 (1971).

$6 \quad$ Starke's International Law, $11^{\text {th }}$ ed, 1994, 65. See also his more extensive analysis of this question, as a young scholar, in (1936) 17 British Yearbook of International Law 66-81. 
It might be said that Joe Starke never fully achieved the recognition in Australia that he justly deserved. He felt keenly the failure to be awarded the title of professor in his own country (although he claimed that title through his various visiting positions abroad). His early collaboration with Professor Stone led to disappointment. He preferred a research position at ANU to a faculty teaching position that would have made him a father figure to generations of students. He was a shy man who did not seek the limelight. His work, however, places him among the greatest international lawyers Australia has produced.

His wife Irma, whom he married in 1943, and a daughter survive him.

Ivan Shearer
Professor of Law, Retired
Faculty of Law
The University of Sydney

